\title{
Algunas claves de lectura para interpretar la mediación kantiana en MVLI y SL
}

\section{Some Reading Keys for Interpreting Kantian Mediation in Mario Vargas Llosa and Shining Path}

\author{
Fermín Cebrecos \\ Universidad de Lima
}

\section{RESUIMEN}

Como parte integrante del libro que lleva por título Lituma en los Andes y la ética kantiana. Idearios ético-políticos de Mario Vargas Llosa y Sendero Luminoso (2017), este texto aborda un problema que, planteado interrogativamente, es enunciado así: "¿Qué posición adoptaría Mario Vargas Llosa ante el formalismo ético kantiano y ante una moral que, como la de Sendero Luminoso, constituye, en muchos aspectos, su negación más antagónica?". La hipótesis de trabajo, elaborada deductivamente, a partir de la novela Lituma en los Andes, es la de que Mario Vargas Llosa muestra, a través del lenguaje ficcional, una marcada predilección por la ética kantiana. Sin embargo, como en su ideario ético político cobra centralidad una dimensión crítica aplicada también al universo del que proceden sus convicciones, se reflexionará aquí sobre ciertas claves hermenéuticas que ayudarán a comprender mejor la hipótesis planteada.

\section{Palabras clave:}

Ética deontológica / Ética material / Razón práctica pura / Razón histórica / Humanismo restringido / Mito / Naturaleza humana / Fundamentalismo / Fanatismo / Diálogo / Autonomía / Heteronomía / Reino de los fines

\begin{abstract}
As an integral part of the book entitled Death in the Andes and Kantian ethics. Ethical-political ideals of Mario Vargas Llosa and Sendero Luminoso, this text addresses a problem that, posed interrogatively, is stated as follows: "What position would Mario Vargas Llosa adopt before the Kantian ethical formalism and before a moral that, like that of Shinning Path, is, in many ways, its most antagonistic denial?" The working hypothesis, elaborated deductively from the novel Death in the Andes, is that Mario Vargas Llosa shows, through fictional language, a marked predilection for Kantian ethics. However, as in its political ethical ideology, a critical dimension is also applied to the universe from which its convictions originate, we will reflect here on certain hermeneutical keys that will help us to better understand the hypothesis.
\end{abstract}

\section{Keywords:}

Deontological Ethics / Material Ethics / Pure Practical Reason / Historical Reason / Restricted Humanism / Myth / Human Nature / Fundamentalism / Fanaticism / Dialogue / Autonomy / Heteronomy / Kingdom of the Ends
$\mathrm{D}$ esde la perspectiva de Lituma en los Andes (en adelante $L A$ ), cabe preguntarse: ¿Qué posición adoptaría Mario Vargas Llosa (en adelante MVLI) ante el formalismo ético kantiano y ante una moral que, como la de Sendero Luminoso (en adelante $\mathrm{SL}$ ), constituye, en muchos aspectos, su negación más antagónica?

Por lo pronto, hay que partir de una hipótesis obvia: quien dice "Lituma" dice también MVLI, y quien dice MVLI ha de poner en juego, ciertamente, a un Lituma ubicado en los Andes, pero también ubicable en un país del primer mundo que podría ser, intencionadamente, el lugar ético que MVLI desea para el Perú. Este trasvase de lo nacional hacia lo ecuménico testimonia la confianza vargasllosiana en una razón que, al modo de Kant, pueda administrarse mediante parámetros éticos válidos para todos los seres humanos. Su Lituma se sentiría, por consiguiente, más a gusto con la ética kantiana que con la de SL. De esta última MVLI deja testimonios elocuentes de rechazo en $L A$. Pero una tesis como la de la predilección por la ética formal tiene que ser cuidadosamente matizada, máxime si se toma en cuenta que en el pensamiento de MVLI cobra centralidad una dimensión crítica aplicada también al universo del que proceden sus convicciones, hecho del que se hará cargo la parte que viene a continuación. En ella, configurada por el esfuerzo de dar cierto carácter 
sistemático a las dos anteriores, se procederá a describir, en una especie de marco teórico específico, tres restricciones comunes a la ética formal kantiana y a la ética senderista, así como a trazar, en clave hermenéutica, la vinculación entre razón-verdad -mito-revolución.

\section{Tres restricciones éticas compartidas}

\section{La ética kantiana y la ética marxista como éticas "ideales"}

Al estar basada en una "idea" (la "idea del deber" = deón), la ética kantiana asume la característica de "ideal", esto es, su norma sintética (el "imperativo categórico") nunca podrá cumplirse totalmente en las acciones humanas. Representa, por ello, un modelo, un "paradigma", una meta inalcanzable. Puede afirmarse que la "idea del deber", al existir solo en la mente, ha de servir de guía orientadora para el comportamiento humano, aun a sabiendas de que nunca podrá actualizarse totalmente en la praxis.

Se trata, pues, de una ética deontológica que puede ser calificada de asintótica. La asíntota es una línea que nunca da alcance a otra línea y, en este sentido, quiere decirse que lo que el ser humano haga, en la práctica, jamás será exhaustivamente coincidente con lo que ordena el imperativo categórico. Este debe desempeñar un rol de "faro" 0 de "estrella" que ilumine la conducta de los hombres, conducta que nunca podrá cumplir a cabalidad debido a lo ordenado por la "conciencia moral", ya que no hay total coincidencia, en los seres humanos, entre "razón pura práctica" y "voluntad".

Tal como ya se ha visto repetidamente, a Kant le interesa fundamentar su ética metafísica en principios a priori, universales y necesarios, subsumidos en un único imperativo categórico, sin tomar en cuenta cómo los seres humanos se comportan realmente.
Por consiguiente, el formalismo kantiano no se basa en la experiencia (en la antropología física o cultural, en las circunstancias históricas, en el componente físico del sujeto), sino que tiene a la "conciencia moral" como su única fuente originaria y legitimadora.

Dicho de otro modo: Kant no toma en cuenta la debilidad e imperfección de la voluntad humana en lo concerniente a su no coincidencia con la razón pura práctica. Su ética está elaborada como si el ser humano fuera solamente "razón", y como si esta, que es objetiva, se identificase con la "subjetividad". Eso solo podría darse en un "ser perfecto", de ahí que se haya afirmado que Kant ha construido una ética ideal apropiada en exclusiva para dioses y no para seres humanos en los que la "subjetividad" (viejo yo) y la "objetividad" (razón pura práctica) son dos entidades no equivalentes. Únicamente en un ser perfecto la ley se identifica con la esencia de su existencia, puesto que coinciden en él subjetividad y objetividad. En el ser humano, en cambio, "solo puede pensarse en función de una voluntad éticamente defectible" y, por lo tanto, guiada por motivos ajenos a la ley moral (Aleu Benítez, 1987, p. 237). Ahora bien, el hecho de que la ética kantiana sea "impracticable" en cada una de las acciones de la praxis no significa que ha de constituirse en obstáculo insalvable para que los seres humanos se esfuercen voluntariamente por ser "kantianos" y aspiren a modelar su conducta desde una ética que manda, como imperativo regulador y único, a considerarnos a nosotros mismos y a los demás como "personas" $y$ no como "cosas".

También la ética de SL, al fundamentarse en una antropología filosófica que parte no de lo que el ser humano es, sino de lo que debe ser, es una ética ideal. Tan utópico como el reino kantiano de los fines es el comunismo, y más todavía en la forma simplificada en que SL lo representa. La consecución de una sociedad igualitaria en la que, por fin, desaparezca la explotación del hombre por el hombre y se dé a cada uno según su necesidad es una meta tan inalcanzable como la pretensión de que, bajo la aceptación de la hipótesis de una razón pura, todos los seres humanos coincidirán en una conducta desembarazada de la subjetividad.

Así, pues, mientras que para Kant la hipótesis de la existencia de una razón pura se constituye en la justificación del imperativo categórico, para SL es la hipótesis de una sociedad comunista la que debe fundamentar toda la praxis revolucionaria. Desde luego que, kantianamente considerada, se trataría de una ética empírica y, por ende, poblada de imperativos solamente hipotéticos convertidos en "medios para" I0 único que es un "fin en sí mismo": la sociedad marxista-leninista-maoísta -pensamiento Gonzalo. La hipótesis deviene aquí, en definitiva, en la finalidad del imperativo, y ya su cuádruple componente testimoniaría que dicho imperativo, al no ser "uno" ni "único" en SL, tampoco podría adjetivarse de "categórico".

Pero la aproximación al logro de una sociedad ideal, meta última tanto de la ética kantiana como de SL, no solo difiere en el punto de partida, sino en la metodología a emplearse para advenir al fin. El punto de partida para el marxismo no es el de una universalidad humana que, gracias a su identificación con una racionalidad común, posee la misma dignidad. Es, más bien, el de una sociedad dividida injustamente en clases y en la que, por dicha causa, no todos los seres humanos están investidos de idéntico valor. La identidad del sujeto y la identidad nacional quedan absorbidas por una identidad de clase que se abre hacia un universalismo de otro corte: el de las clases proletarias del mundo. Asimismo, en la interpretación que SL hace de la realidad todos los medios para acceder a una sociedad comunista son éticamente irreprochables, de suerte que hasta el quitar la vida a los otros se convierte en un deber. Ya se ha visto que en Kant, por el contrario, el ser racional nunca debe usarse como medio y no puede ser desplazado de su cúspide ontológica, en cuanto valor supremo, por nada ni nadie: ni por el partido, ni por la ideología, ni por ningún condicionamiento político. La ética kantiana no permitiría hablar de crímenes cometidos en nombre de la razón; habría que atribuírselos, más bien, a una razón que, mezclada con 
las impurezas de la subjetividad, se guía por máximas y no por principios objetivos. Sin embargo, en la ética marxista las acciones criminales sí pueden ser justificadas racionalmente por ella, ya que constituyen un medio sin el cual no podría arribarse a la meta final.

MVLI es, en este aspecto, decididamente kantiano: los regueros de sangre que dejó SL llevan la marca de la irracionalidad, puesto que nadie puede ser obligado, mediante ningún acto de cooptación, a pagar con su vida las exigencias de la ideología comunista. La pretensión de imponer a la fuerza un "deber ser" habla ya, por sí sola, de que la necesidad de la ley no es "vista" como universalmente buena y, por ende, el ideal de la revolución proletaria solo estaría representado en la conciencia de un segmento de la sociedad, el cual tendría el deber moral de hacer que todos lo cumplan. También Kant rechazaría de plano tal heteronomía.

Si en el ser humano, en su conciencia moral, anidan ideas universales a las que la voluntad debe acomodarse de manera exhaustiva para transformarlas en acciones, ¿puede hablarse de una humanidad autónoma? El problema posee similitudes con el que se planteó Guillermo de Ockham respecto de la voluntas Dei. Su solución, coincidente en este punto con la de Tomás de Aquino, fue la de identificar en Dios el entendimiento y la voluntad (Hirschberger, 1965, pp. 446-447), identificación que Kant trasladará, mediante la ecuación razón práctica = voluntad, a un ser humano existente solo como idea. El vínculo que une, en nudo similar, las éticas kantiana y marxista es el de la utopía. Lo utópico, etimológicamente considerado, significa "lo que está sin lugar", lo que no puede mostrarse como presente en el espacio-tiempo. Hay diversas clases de utopías (individuales, políticas, científicas, literarias), pero todas ellas se mueven al compás de una idea previa no transformada -ni transformable - en realidad. Ahora bien, mientras unos (Kant y MVLI) afirman que la idea jamás podrá actualizarse por entero, otros (SL) sostienen, apelando al futuro y fundamentándose en que las grandes transformaciones polí- ticas comenzaron siempre enlazadas a una utopía, que sí se encarnará en la realidad. Sucede que mientras Kant ofrece un universo ético que no "pende del cielo ni se apoya sobre la tierra" (Fundamentación de la metafísica de las costumbres, en adelante FMC, p. 112; Ak IV, núm. 425), al marxismo le mueve la fe de estar firmemente asentado en la realidad terrenal. Sin embargo, la reconvención que Ernst Bloch le hacía a Kant por presentar, en su ética, "un océano sin orillas" (“¿Qué consuelo —añadía — obtiene de ello el náufrago, o también el viajero, en cuyo horizonte no se divisa ninguna llegada posible?") (1985, p. 225), también puede aplicársele a la lectura marxista de una sociedad sin clases.

El imperativo categórico kantiano es una idea, y lo mismo la que subyace, como acicate revolucionario, en torno del advenimiento de una sociedad comunista. En ambos casos se trata de un "deber ser" que pretende trasladarse a un "ser", tanto individual como social, necesitado de corrección ética. Pero la idea marxista, al requerir en su praxis el aniquilamiento de los enemigos de clase, no puede liberarse de ser una utopía sangrienta, mientras que la utopía kantiana exige un constreñimiento de la voluntad, que aspira, más bien, a una coexistencia pacífica de todos los seres racionales. Si se aplica aquí el filtro de la razón —entendida, incluso, como "razón histórica" - ninguna de las dos ideas (ni la kantiana ni la marxista) podrán trasladar a la realidad las virtualidades en ellas contenidas y, en ese sentido, ambas conservarán por siempre su carácter utópico. Por un lado, ningún formalismo ético podrá convertirse en realismo y, por otro, ningún marxismo real, como lo testimonia empíricamente la historia, concuerda del todo con la idea que lo promovió.

MVLI ha dedicado una parte significativa de su producción intelectual a someter a crítica los diversos tipos de utopías. Excede los límites de estas reflexiones detenerse en su contenido específico, pero su posición —como se verá más adelante- puede sintetizarse en términos elocuentemente negativos.

\section{La ética kantiana se basa en un supuesto metafísico hoy inadmisible, así como es también racionalmente inexcusable la metodología ética de SL}

Kant fundamenta su ética en un supuesto (hipótesis) que en la actualidad es negado tanto por la ciencia como por la filosofía. El supuesto está vinculado al dualismo cartesiano, en el cual se conceptúa al ser humano no como una unidad psicosomática, sino como un compositum claramente discernible en dos elementos independientes: la res cogitans (alma, espíritu, mente, razón) y la res extensa (lo corpóreo, lo material, la subjetividad). Kant, deudor de esta concepción racionalista, separa tajantemente la "razón pura" de todo aquello que no es racional, creando así una ética cimentable exclusivamente en los principios de la "conciencia moral" (= razón pura práctica) y no tomando en cuenta que el ser humano es también corporalidad y materia. Mente y cuerpo siguen siendo, para él, dos substancias ontológicamente separables.

Dicha posición tiene como consecuencia que Kant interprete la "razón pura" sin sujeción a evolución alguna, sino, antes bien, tal como sucede con el "alma" cartesiana, en términos de una permanencia ontológica estática e inmutable. De ahí se deduce que, kantianamente hablando, lo que es bueno (y verdadero o bello) para un griego anterior a Cristo debe serlo también para un peruano del siglo xxI, puesto que se parte de la hipótesis metafísica de que todos los seres racionales poseen una razón idéntica e impermeable a los cambios producidos en la naturaleza y en la historia.

Sin embargo, la ciencia puso de manifiesto a través de la teoría de la evolución natural (Darwin, 1859) que el ser humano proviene de otras especies animales, confirmándose, posteriormente, mediante la teoría del "gran estallido" (big bang), que nuestro "viejo yo" tiene una edad aproximada de trece 0 catorce mil millones 
de años. En efecto, la materia de la que está compuesto el ser humano proviene de las consecuencias de una gran explosión que devino en materia inorgánica, orgánica, viva, cerebralizada y consciente. La ciencia, pues, sostiene que el ser humano es producto de una evolución cósmica natural, y que la vida pudo llegar a nuestro planeta mediante una lluvia de meteoritos 0 en las colas de cometas que, en ese entonces, disponían de abundante material orgánico y que pudieron sembrar de bacterias la biósfera en su choque con la Tierra. Aun cuando no es universalmente aceptada, la teoría de la panspermia, defendida principalmente por los astrofísicos Fred Hoyle y Nalin Chandra Wickramasinghe, constituye también un alegato científico en pro de la evolución cósmica. Llama la atención que Kant, que había publi-

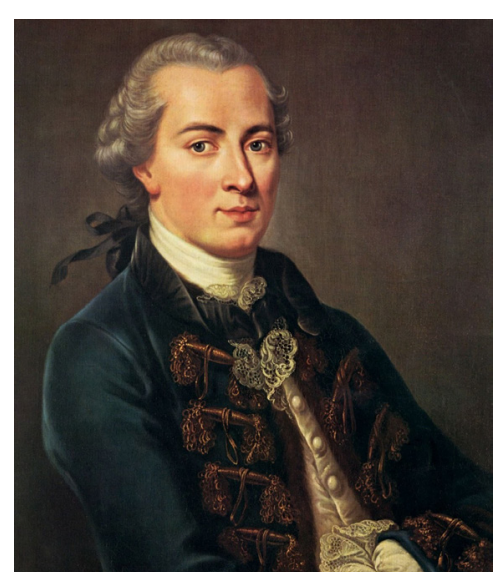

El joven Kant

cado, en 1755, su obra Allgemeine Naturgeschichte und Theorie des Himmels, y defendido en ella, en contra del "primer motor inmóvil" aristotélico, la formación del sistema planetario a partir de una nebulosa protosolar, no explicase evolutivamente la aparición del fenómeno humano. Aunque pionero de un modelo universo autosustentado (self sufficient universum), era imposible para él que la razón proviniese de "lo otro" de sí misma, y sobre esta convicción se encuentra asentado su formalismo ético. Lo que habría sucedido, en el ámbito de su ética, si Kant hubiese conocido la teoría darwiniana, pertenece al saber de lo futurible, pero, de aceptar la evolución, como aplicable al origen y desarrollo de la especie humana, no podría haber proclamado una "metafísica de las costumbres" fundamentada exclusivamente en la razón pura. La filosofía, que no debe permanecer nunca desatenta a los datos de la ciencia, tampoco defiende actualmente la posición de una razón renuente a ser condicionada por el espacio-tiempo. Especialmente a través de las reflexiones de Dilthey, Ortega y Gasset y Sartre, se ha dejado en claro que la razón humana es una razón histórica y, por ende, está sometida a los cambios culturales y sociales que se originan y desarrollan en la historia.

No puede, pues, sostenerse, desde este doble frente (el científico y el filosófico), el supuesto metafísico de la existencia de una "razón pura", la cual, por otra parte, no admitiría que la conciencia humana pudiese ser "formada" ni "deformada". Ello va en contra de los postulados de las teorías educativas, ya que estas tienden, además de aportar "instrucción", a "formar" la conciencia humana desde perspectivas éticas y axiológicas, esto es, pretenden "educar en valores" y lograr que las acciones humanas se ajusten a "buenas" pautas de conducta.

También resulta inadmisible la metodología marxista que ha de emplearse para la consecución del objetivo final, especialmente después de las experiencias históricas que avalan la no legitimación de la hipótesis. SL, tal como se ha visto en $L A$, puede ser interpretado, no sin motivos, como un remedo del marxismo teórico, pero es susceptible, por lo menos en dicha novela, de ser leído a la luz de una deformación de la praxis marxista. La caricatura senderista demuestra, sin embargo, que una metodología que se presta a ello tiene que ser racionalmente desechada, con el agravante de que, en este caso, el ejemplar y la copia demostraron su inadmisibilidad en su aplicación práctica.

\section{Tanto la ética kantiana como la marxista son testimonios de un humanismo restringido}

Teniendo en cuenta que el "humanismo", filosóficamente considerado, se asienta sobre dos pilares inconmovibles: a) el considerar al ser humano como el valor supremo de todo lo existente, y b) el tratar al otro como a uno mismo, ha de afirmarse que la ética kantiana es "humanista", puesto que ambas premisas se cumplen en su enunciado del imperativo categórico.

Ahora bien, el hecho de que en Kant pueda hablarse de un "humanismo restringido" se debe a que, para él, solo puede ser considerado "humano" el poseedor de las tres características anteriormente descritas y vinculadas, en nexo irrenunciable, a la "razón pura práctica”: capacidad de introspección, encuentro de un imperativo común (que no es otro que el imperativo categórico) y posesión de una voluntad o libre albedrío para actuar (o no actuar), siguiendo los principios de la conciencia moral. Así, pues, solamente en seres que ostenten dichas características ha de ponerse en práctica el humanismo, no importando en absoluto la apariencia somática con la que dichos seres puedan estar revestidos.

De ahí ha de colegirse que un marciano podría muy bien constituirse en un ser racional y que puedan practicarse la eutanasia y la pena de muerte en caso de que se demuestre que un individuo carece de racionalidad. Efectivamente, si el ser humano no es racional, entonces puede ser tratado como "medio para" y no como "fin en sí mismo", ya que el hombre posee un valor supremo si y solo si es depositario de las tres características que Kant asigna a su "naturaleza". De igual modo, en la ética kantiana no tiene cabida ninguna clase de "racismo" ni ningún privilegio, ya sea cultural o moral, fundamentado en la subjetividad. Tampoco el multiculturalismo, cuando es interpretado en el sentido de que todas las costumbres y creencias de una determinada cultura gozan de inmunidad moral, o el eurocentrismo, que otorga credenciales de superioridad a todo lo europeo, tienen cabida en la ética kantiana. $Y$ también se deriva de lo anterior que los animales, al estar desposeídos de racionalidad, puedan ser tratados 
como lo que realmente son ("cosas") $y$, por ello, ser usados para los fines que el ser racional determine: alimento, diversión, o mercancía ${ }^{1}$.

Las restricciones del humanismo marxista vienen impuestas por su transgresión de los dos pilares en que se sustenta el humanismo a secas. El ser humano, en la ideología de SL, poseerá un valor supremo solo una vez que se alcance la sociedad comunista; antes — como LA lo pone de manifiestotodos los hombres son medios (desde luego, jerárquicamente estatuidos) para lograr ese fin. Por consiguiente, tampoco ha de tratarse al otro como a uno mismo, a no ser, como sucedió en el caso de Pedrito Tinoco, que se le incluya en una clase social que resulta siendo, a la vez, redimible y redentora: el proletariado.

SL es, en $L A$, un epifenómeno, en cierta medida predeterminado, del humus histórico (barro, sangre, instintos, razón, fe catártica) que constituye el ser del hombre en general y que, en el caso del Perú, tiene sus propios meandros (incanato avasallador, conquista española, resentimientos legitimadores, racismo, superstición). Kant, en una psicología racional emparentada con los órficos y con Platón, Descartes y la teología paulina, concibió la esencia humana (el to on de los griegos, el esse de los latinos) como lo no vinculado en absoluto a lo material y desembocó, así, en una entelequia a priori que, aplicada a la razón práctica, se convirtió en la "idea del deber" (deón). De este modo, la ecuación ontológica ser "humano = ser puramente racional", dictaminada por una razón autocalificada de "pura", se erigió en clave interpretativa de una ética formal que despojó a la conciencia, en tanto que lugar de encuentro de las leyes morales, de todo contacto con lo material. La "animalidad" (animal rationale), que Aristóteles atribuía también al ser humano (ánthropos = zoon lógon échon), y que, de un modo u otro, está presente al igual que en Platón, en su teoría de las "tres almas" (vegetativa, sensitiva racional), es, en consecuencia, el obstáculo a eliminar. $Y$, con ella, se proscribe, como fundamento de la moral, todo lo relacionado con las impurezas de lo contingente: mundo externo, historia teología revelada, credos ideológicos. La ética kantiana no habla el lenguaje de la antropología filosófica actual y, por consiguiente, tampoco concibe al ser humano como una unidad psicosomática, aunque la inseparabilidad mente-cuerpo no supondría para Kant, como sí sucedía en un pensador teísta como Descartes, una barrera racional para la creencia en la inmortalidad del alma y en la resurrección del cuerpo.

Este concepto de "humanidad", identificado esencialmente con el de "razón pura", es el que garantiza el empleo de la facultad de la representación de la ley moral y el encuentro, dentro de la razón práctica de un imperativo categórico universalizable. Ahora bien, cabe preguntarse aquí: ¿Qué es lo que se representa un senderista cuando, empleando también el método introspectivo, se sumerge en su conciencia moral? Necesariamente tendrá que encontrar principios prácticos, esto es, normas expresadas en un modo verbal imperativo, solo que ahora todo este arsenal legal, a diferencia del imperativo categórico kantiano, no se dirigirá al deber de tratar al otro como a uno mismo, sino, más bien (tal como lo testimonian los casos de los turistas franceses, Barbara d'Harcourt y Andamarca) al deber de arrebatarle la vida. Las diversas formas de eliminar al otro, en gradual aplicación de la crueldad, constatan que SL también aplicó la pena de muerte basándose en las diferencias que su propia interpretación de la razón atribuía a las víctimas.

Desde luego que los senderistas, al igual que los que ejercen de antropófagos en $L A$, pueden ver interiormente, mediante del uso de la facultad representativa de su razón, lo que en su interior se contiene. Resulta indiscutible, entonces, que ejercen de seres racionales, pero su visión, entorpecida por elementos ajenos a la razón, no encontraría en la conciencia moral el imperativo categórico con el que se topa una mirada desprovista de subjetividad. Desde esta perspectiva, ¿sería un senderista, kantianamente considerado, un ser "humano" que podría constituirse en miembro de un "reino de los fines"? Imposible no reconocer, en esta coyuntura, que la drasticidad con la que Kant desvincula la razón de eventuales influencias empíricas no está inmune de desembocar en un fundamentalismo de similar arquetipo que el de SL: los seres carentes de razón han de ser tratados siempre como "medios para" y no como "fines en sí mismos". Tampoco la razón pura estaría exenta, según esto, de crear monstruos propios.

\section{El mito de la verdad y la verdad del mito}

A un escritor de innegable filiación ilustrada como MVLI le es connatural el esclarecimiento racional de lo que sucede en su derredor. LA constituye un testimonio de que, aplicadas a la realidad peruana, "las circunstancias del universo en que el ser humano está puesto" (FMC, p. 64; Ak IV, núm. 389)

1 Durante los últimos años, en el curso de Filosofía dictado en el Programa de Estudios Generales de la Universidad de Lima fueron estudiados cuatro artículos de MVLI de clara naturaleza ética: "La señal de la cruz" (1995), "El nasciturus" (1998), "E sexo débil" (1998) y "Los pies de Fataumata" (1999). En todos ellos puede detectarse la vigorosa impronta de la racionalidad kantiana, huella que, sin embargo, parecería extenderse también a la justificación, irracional para muchos, de las corridas de toros. MVLI considera su eventual supresión como un "agravio a la libertad" y como una "manera prepotente y demagógica" de desarraigar una "seña de identidad". No emplea como argumento la ecuación kantiana animales = cosas; más bien, cree que el amor a las corridas de toros está supeditado a otros "amores" superiores: la no extinción de los toros bravos y el derecho irrestricto, por humano, al usufructo de la libertad. De problemática tan escurridiza para la ética kantiana no se libran dos artículos relativamente recientes de MVLI: “Torear y otras maldades" (2010) y "La 'barbarie' taurina" (2012). Si se ve una "clara continuidad" — como pone de manifiesto Rosa Montero- entre el cosificar a nuestros semejantes y el no sentir empatía por el sufrimiento de los seres vivos ("Continuidad", El País, 10 de febrero de 2015), entonces tanto Kant como MVLI merecerían un desacuerdo "emocional". 
han de ser, en la vertiente kantiana de la llustración, valoradas negativamente por la luz de la razón y, en su vertiente marxista, también racionalmente transformadas. Este doble componente ilustrado se encuentra actuante en una novela en la que las afecciones subjetivas, en combinación que diluye los límites entre lo animal y lo humano, se imponen sobre los requerimientos racionales. Fernando $R$. Lafuente, en el prólogo de $L A$ (1993), lo describió así: una "historia que recrea cómo el instinto, arraigado en lo más profundo y en lo más oscuro del ser, se resiste a la razón o cómo la razón y el progreso se enfrentan a la pérdida de la pasión, del goce, de la emoción ancestral".

Descubrir esta relación implica movilizar la razón como árbitro diferenciador entre lo que es racional y lo que no lo es, pero también entre las diversas jerarquías en que lo racional se autocomprende a sí mismo. En esta empresa, a no dudarlo, es MVLI más kantiano de lo que puede aparecer a primera vista, no obstante que en su estilo difiera claramente de ello y acoja, con lirismo y humor románticos, "Io otro de la razón". Pero incluso en novelas que, por su contenido, están inmersas de lleno en lo que Kant denominaría "subjetividad" (como, por ejemplo, Elogio de la madrastra, Los cuadernos de don Rigoberto y Travesuras de la niña mala) le guía, impulsado por lo racional, un afán "ilustrador", sea para, en este caso, diferenciar el erotismo de la pornografía, o para aprender a liberarse de prejuicios que, venidos de la religión y de una ética tradicional reñida con el sexo, mantienen al ser humano en la caverna de la irracionalidad.

Pero la razón humana no surgió de la nada. Tiene su génesis en una naturaleza lato sensu, es decir, en una naturaleza física (physis) que, en despliegue de sus potencialidades y luego de una trayectoria cronológica de alrededor de catorce mil millones de años después del Big Bang, se actualizó en homo sapiens sapiens. Tomando en propiedad los términos del libro I de la Ética de Spinoza, aunque su raíces provengan de Aristóteles y Averroes, puede afirmarse que la natura naturans produjo la natura naturata del ser racional (su autoconciencia), última estación, por ahora, en la evolución del universo. Sin embargo, no ha de pensarse que el proceso de conversión de natura naturans en natura naturata se inició con la aparición de la vida: ya antes, en la fisióesfera, el principio activador de la naturaleza contenía en germen lo que se iba a producir en la bióesfera. En consecuencia, la natura naturata de la razón humana, lo mismo que otras determinaciones concretas del proceso evolucionista, no se identifican con una realidad estática y dada para siempre; por el contrario, convertida ella misma en natura naturans, es causa, en su dimensión de razón práctica, de una ética cuyos imperativos no pueden librarse tampoco de la evolución.

Kant no conoció la teoría de Darwin y, por lo tanto, no dispuso de un modelo teórico — como sí fue el caso de la Crítica de la razón pura, con relación a la física newtoniana - que, proveniente de la ciencia, contribuyese a fundamentar su ética. Separó, por ello, la "pureza" de la razón práctica de toda contaminación o injerencia empíricas y salvaguardó así, en un conato de total idealización, los imperativos morales, dándoles una validez sempiterna e inalterable. Pero una ética tan desarraigada del proceso, siempre en devenir y nunca consumado, de la natura naturans no puede ser sino una entelequia principista que no se condice con los datos de la antropología empírica. En efecto, partiendo de una racionalidad sin nexo alguno con su matriz material, ¿cómo podrá sostenerse que nuestros antepasados practicaron la antropofagia en la lucha por la vida y que algunos de los que hoy se consideran crímenes nefandos (el incesto, por ejemplo) fueran en otro tiempo coincidentes, de un modo u otro, con la razón? ¿Desde cuándo la razón, interrumpiendo su proceso evolutivo sedimentándose en una instancia impermeable a todo cambio, se erigió en creadora de una moralidad perpetua? Al igual que en la historia natural de la evolución humana, también aquí ha de dejarse constancia de una línea evolutiva que, remontándose a los órficos, tendrá en Platón, el cristianismo y Descartes, cuatro estadios teóricos sin los cuales Kant no podría ser entendido.

Las éticas materiales se acomodan mejor a esta realidad evolutiva humana, aunque corren el peligro de idealizar, totalizándola, una porción de dicha realidad. Tal como sucedía con los prisioneros de la caverna platónica, puede contemplarse un segmento de lo real con tanta claridad e insistencia que se corre el riesgo de confundirlo con toda la realidad $y$, de este modo, transmutarlo en una convicción inmune a toda crítica racional. Pero la convicción no se queda solamente en una constatación teórica. En determinados fundamentalismos políticos y religiosos va acompañada de la propia inmolación para defender verdad tan parcial y de la eliminación del que no comulga con ella.

En SL no se trató, entonces, de una descalificación meramente teórica del rival. Al adoptar un modelo doctrinario extremadamente simplificado, los senderistas se acoplaron a un pensamiento único que, desde la verticalidad del líder, decretaba quién tenía que vivir y quién tenía que morir, logrando, en este caso, que la imposición forzada de un monólogo dogmático amputase todas las posibilidades de diálogo con el enemigo de clase. Kant afirmaría, en interpretación acorde con MVLI, que este patrón de conducta, sometido a una razón crítica, dejaría como saldo el triunfo de la irracionalidad más absoluta. Pero la razón histórica tampoco se aviene del todo con una interpretación exclusivamente racionalista, y los marxistas podrían alegar que la pureza de la razón kantiana, al no estar fundamentada en la realidad empírica, no se ve libre de acarrear injusticias, eternizarlas en un statu quo conservador y coadyuvar, con su silencio aquiescente, a la explotación del hombre por el hombre. Hay, sin embargo, un signo de identidad común: tanto en el formalismo kantiano como en el marxismo senderista la verdad acaba por convertirse en mito. Kant pretendió, aislando el imperativo categórico de toda contaminación subjetiva, desentrañar críticamente el factum de una razón práctica pura, pero consiguió, de este 
modo, convertir su ética en un relato aséptico en el que la realidad humana no se ve reflejada y al que no puede dar crédito una razón que es, en esencia, tan lógica como ilógica en su comportamiento práctico (Paul, 1990, pp. 44-45; Morin, 1973, pp. 123-124)2. Paralelamente, las leyes de la historia natural, aplicadas en el materialismo histórico a la sociedad, son tan implacables como debe serlo la praxis marxista, la cual, a su vez, ha tenido que depurarse de otros imperativos provenientes de una historia humana de mayor complejidad y riqueza que la natural. De lo que aquí se trata es, sin embargo, de convertir lo "artificial" de la revolución en una verdad "natural" que la realidad ha forzado a devenir en mito: la implantación de la sociedad comunista tendrá que ocurrir en una historia regenerada por la previa lucha de clases. No resulta improbable que muchos senderistas, que escucharon en las aulas universitarias el mensaje optimista de un comunismo que, quiérase o no, tendría que acabar por imponerse necesariamente en el Perú y en el mundo, se convirtiesen en aliados incondicionales del proceso y tuvieran la conciencia de que, empuñando el fusil, acelerarían la consecución de la meta.

La interpretación de la verdad, sea kantiana o marxista, como mito, es, desde luego, una conquista de la razón, única instancia para desmitificar dicho proceso. ¿Qué resta, sin embargo, luego de dicha desmitificación? Por más paradójico que parezca, y poniéndose de relieve una vez más la inextricable combinación de mythos y logos, ha de afirmarse que también el mito contiene verdad y que corresponde a la razón llevar a cabo su "desracionalización". Pero este cometido será incumplible, ya que los grandes mitos se alimentan de mitos menores, se mimetizan en racionalidades aparentes $\mathrm{y}$, en último término, se reinventan a sí mismos, especialmente cuando se trata de mitos políticos como el de la justicia y la libertad, renuentes a encarnarse en un topos real.
El componente utópico es propio, en consecuencia, tanto de la ética marxista como de la kantiana. Está claro que los senderistas, inmersos en una suerte de subjetividad rizomática imposible de ser exhaustivamente conceptualizada, no han de vincularse a ninguna ética formal. Tampoco los custodios del orden ("¿de qué orden?" - -se preguntarían aquí tanto MVLI como los senderistas) pueden constituirse en representantes de la ética kantiana. ¿Podría serlo Lituma, cuyo sentido común parece ser, en ocasiones, coincidente con la universalidad de la razón? ¿O MVLI, quien es el que dirige a Lituma en su conducta y enjuiciamiento éticos? La respuesta ha de ser, en todos los casos, negativa, puesto que la ética kantiana no admite más que un representante teorético: el de una razón pura liberada de todo "agente" y de todo modelo a imitar. A la par, la razón que interviene en la ética de SL decretará que una superestructura como la del imperativo categórico, al estar desvinculada de una base "terrenal", no podrá sino constituirse en un asidero metafísico del estado de cosas imperante y, por ello, tendrá que ser desenmascarada como lo que realmente es: una alienación ideológica.

Tampoco el "reino de los fines" está exento de que, en el afán de materializarlo, se tenga que tratar al otro como medio para un fin del que se está convencido que es superior. Pero hay diversas maneras de tratar al otro como medio. Y la propugnada por el mito de la razón pura se encuentra en las antípodas de la que, en versión de SL, enarbola el mito de la sociedad comunista: matar al otro en nombre de un mito, para que este se encarne en la realidad social, es lo que le concede irracionalidad 0 , lo que es equivalente, imposibilidad de ser racionalmente justificado. En este enfrentamiento de dos mitos antagónicos no puede, sin embargo, desatenderse la verdad de que tanto el "reino de los fines" kantiano como la etapa final de la revolución marxista constituyen, pese a sus diferencias, la idealización de un objetivo caracterizado en ambos casos por la utopía. También en ella habita la verdad del mito. Mas así como es competencia de la razón establecer jerarquías entre lo racional, también lo es hacer lo propio con lo mítico. Y, en esta labor crítica, distinguirá cuál de los dos mitos (el del formalismo de la ética kantiana y el de la ideología senderista) contiene más verdad. $L A$ es, en este contexto, la respuesta de MVLI.

\section{El mito de la "razón pura" y el mito de la revolución pura}

Kant, como representante eminente de la Ilustración, otorga a la razón humana el poder irrevocable de dirimir lo que es moralmente valioso. Creyente también en la filiación ilustrada del hombre actual, MVLI postula una ética política en la que sea la razón, y no la arbitrariedad y el abuso (FMC, $\mathrm{p}$. 116; Ak IV, núm. 428), la que dirija el comportamiento humano tanto en su ámbito individual como, sobre todo, en su dimensión social. De la coincidencia en determinados ideales de la llustración se origina que la voz de Kant esté presente en muchos pasajes de su obra, tanto ficcional como ensayística. Que dicha presencia no cuente con el asentimiento intencionado de MVLI demuestra que, en efecto, existen principios universales que, no importando ahora cuál haya sido su génesis, testimonian una identidad ética fundamentada en la racionalidad.

Ahora bien, si al ser humano se le exige "excluir por completo el influjo de la inclinación" en una acción hecha exclusivamente "por deber" (FMC, p. 79; Ak IV, núm. 400-401), ha de suponerse que su naturaleza es "inmixta" (Rodríguez Aramayo, 1987, p. 191). ¿Lo es? Los argumentos que proporciona la ciencia hablan, más

2 En carta que María von Herbert envió a Kant, en 1791, le confesó que ocultaba a su amante un secreto del que no salía mal parada; sin embargo, por atenerse al cumplimiento de su ética y revelárselo, se produjo la separación. Si una obra hecha con placer ya no es, de por sí, virtuosa, la praxis del imperativo categórico — así razonaba María- puede convertirse en la más vacía de las rutinas. La respuesta de Kant, redactada a modo de un sermón deontológico, no la convenció. 
bien, de una evolución que arrastra, antes de la aparición de la razón, un mundo de circunstancias vinculadas a la materia y a la animalidad, y que la razón se encuentra inmersa en ellas y es, de algún modo, su consecuencia. Se impone aquí volver a Aristóteles/ Tomás de Aquino y coincidir con ellos en que el ser humano es un "animal racional" (animal rationale), y que, por lo tanto, la ética ha de tener en cuenta esta naturaleza (on) para definir "cómo deben ser" (deón) sus costumbres (ethos). Pero la "forma de ser" (ethos con eta inicial, y no con epsilón) que Aristóteles deriva de ethos (con epsilón inicial = costumbres) no es algo dado por naturaleza, sino adquirido por el hábito, es decir, por la "repetición de actos semejantes" (Ética nicomaquea, II, 1, 1103 a 17-18; Rovira, 2012, pp. 47-48).

El concepto de naturaleza humana pretende, como todos los conceptos, atrapar estáticamente una realidad que, por su dinamismo, le es esquiva a la mente. Kant identifica dicha naturaleza con una "razón pura", esto es, con una realidad que no existe independientemente del pensamiento, ya que la naturaleza humana es una mezcla irresuelta de "impurezas", provenientes todas ellas de lo que la razón, en su afán por definirse (y la definición supone establecer diferencias), atribuye a "lo otro de sí misma". Una ética metafísica, esencialista y formal como la kantiana no podría encontrar una fundamentación universal y necesaria del deber si es que no propugnase un concepto de naturaleza así estatuido, puesto que lo contrario significaría dejar el campo libre a un relativismo moral.

La aparición de la razón vino acompañada de la conciencia moral, esto es, de una "idea del deber" que no puede, de ninguna manera, interpretarse como una creatio ex nihilo. Se trata de un "deber ser" vinculado forzosamente a un "ser" previo, tan antiguo como el mundo, pero que arrastra tras de sí otras escalas anteriores. Todas estas fases han dejado una sedimentación en el "ser" del hombre, la cual, si se le añade todo lo que históricamente le ha rodeado y le rodea en su estado de homo sapiens sapiens, no puede ser orillada en la fundamentación de su "deber ser".

Pero la relación entre el "ser" y el "deber ser" tampoco puede plantearse como una separación extremista entre "animalidad" y "racionalidad", sino como una "animalidad racional" y como una "racionalidad animal". Ahora bien, el "deber ser" es puesto por la razón como una meta a cumplir, mientras que el "ser", entendido en el ser humano como una unidad psicosomática, jamás podrá agotar en la praxis la dimensión utópica que le impone la "idea del deber". En consecuencia, la tensión entre "deber ser" y "ser", sin la cual ninguna ética es concebible, da fe de que todo planteamiento racional del deber, por más enraizado que esté en "lo otro de la razón", no podrá nunca cumplirse netamente.

Así las cosas, se imponen, cuando menos, dos preguntas: ¿Por qué el ser humano, siendo también animal, ha de comportarme como si no lo fuera? ¿“Lo otro de la razón" tiene que ser siempre y necesariamente contrario a la razón? Cierto que en la naturaleza, entendida lato sensu como totalidad física de la cual procede el hombre, es inadmisible una teleología, esto es, una planificación finalista de lo que ella produce y, por lo tanto, tampoco ha de postularse que la razón haya sido una especie de "correctivo" a planteamientos previos equivocados. Pero lo que no parece discutible es que, admitido su componente animal, se pretenda encontrar en el ser humano una "razón pura" que se aísle de su parte empírica y que se autoproclame en auténtica naturaleza humana. No se trata de ningún reduccionismo materialista que propugne la ecuación ser humano = animalidad, sino de concebir al hombre como una unidad psicosomática que impulse sus acciones y que se constituya en fundamento de sus normas morales. Así, pues, "lo otro de la razón" reclama también sus derechos en la acción y, por ende, la equidad, la justicia, la patria y la libertad, así como la rebelión, el resentimiento y la venganza pueden erigirse también en móviles para actuar. Reconociendo que, en aras de evitar el relativismo moral, le ha de corresponder a la dimensión crítica de la razón la tarea de jerarquizar dichos móviles, no ha de ocultarse que, privada de sus componentes no racionales, la razón se convierte en una entelequia que administra las cuotas de racionalidad como si ella fuera, absolutamente, toda la esencia humana. Dicho de otro modo: le corresponde a la razón (ser hijos de la llustración hace trabajoso abjurar de su herencia) examinar críticamente las presuposiciones en que se fundamentan los juicios morales, aun a riesgo de que también, en nombre de la razón, pueda ponerse en práctica un relativismo ético.

La pregunta clave, en este contexto, ha de plantearse así: ¿Es "naturalmente humano" el ser humano, 0, más bien, la "humanidad" ha de ser un resultado "artificial" al que se adviene mediante la ética? Si el ser humano "no es" humano, sino que "se hace" humano (Comte-Sponville, 2012, pp. 127-131), entonces la ética es un revulsivo contra lo natural (nacionalismo, violencia, racismo) y tendrá que admitir necesariamente normas que no sean absolutas. El nudo del problema reside en definir, de cara a la "naturaleza", qué es la razón. ¿No está acaso, en tanto que razón humana, mezclada de elementos sin los cuales el hombre dejaría de ser tal? ¿Puede hablarse de ella como de una realidad autónoma que se dicta a sí misma sus propias leyes? ¿Por qué ha de convertírsela a priori —al igual que sucede con su correlato: la "buena voluntad" - en una "idea" o en un "hecho" que solamente puede ser legitimado a la luz de la razón misma? Pretender independizarla de sus otros componentes significa conceder a la razón no solo predominancia gnoseológica, sino exclusividad ontológica. Actuando así, ¿no se prescinde injustamente del componente propiamente "humano" de la razón?

La razón - tal como ha sostenido Robert Nozik - se identifica en la práctica con "la capacidad de razonar". Pero "una de las cosas sobre las que los filósofos razonan es el razonamiento mismo" y, más en concreto, sobre cuáles son los principios 
a los que este ha de someterse (1995, pp. 13-14; 97-98). Aun cuando - como decía Karl Popper- no hay razón alguna para desesperar de la razón, Montaigne había advertido ya (Essais, II, 12) que "ninguna razón podrá establecerse sin otra razón", originándose así un regressus ad infinitum en el que la confianza popperiana amenaza con desmoronarse. De lo que no cabe duda es de que, en su afán por fundamentar su propia actividad, la razón ha de perfeccionar no solo el razonamiento, sino también las creencias y las acciones humanas. Claro que ella también puede servirse de argumentos racionales para fundamentar el por qué no ha de independizarse de otros componentes del ser humano y, en actuación despótica, arrogarse solamente para sí la identificación con la "humanidad". Mas, como ya se ha dicho, se entra aquí en un debate circular, propio de la metaética, del que no hay salida posible, a no ser que la razón se sitúe, críticamente, en su real esencia: formar parte de una "humanidad" finita, cuya finitud estribe, principalmente, en poseer una razón también finita, corregible y no impermeable a los fenómenos ajenos a ella. El sí a la "razón pura" pertenece, por lo tanto, a una mitología, con la que, trascendiendo la razón misma, el hombre se autodefine y, de este modo, pretende conseguir lo racionalmente inalcanzable: que haya una sola moral ${ }^{3}$. En la filosofía marxista el concepto de naturaleza humana no se basa en un innatismo gnoseológico; ha de provenir de la experiencia, tal y como le compete a una teoría "fotográfica" del conocimiento que involucra, en su desarrollo, dándoles un rasgo esencial, a las circunstancias socioeconómicas en las que el sujeto individual está inmerso. Dicho concepto no puede liberarse del binomio base-superestructura y, por ende, es tan "falso" como la conciencia en la que él se refleja. Solo removiendo violentamente la injusticia de la base podrá llegarse a una idea de naturaleza humana que, libre de error y concordante con la naturaleza real, pueda erigirse en guía de la ética. Faltaría saber, no obstante, si en una situación de total concordancia entre concepto y realidad la ética tendría cabida.

Jean Paul Sartre, un marxista heterodoxo, no admitió el concepto de naturaleza humana. El existencialismo es un humanismo ([1946] 1999) representa, más bien, un alegato en su contra, ya que el hombre no podría ser radicalmente libre sin desanexarse de un concepto que le propone de antemano lo que él debe hacer. Una vez que se niega la existencia de Dios $y$, con ella, una idea de naturaleza humana ajustada a sus designios éticos, el hombre se definirá por lo que él haga de sí mismo. En consecuencia, cada individuo, al final de su vida, en la sumatoria de sus actos, podrá sellar definitivamente cuál fue su auténtica naturaleza. No hay, para Sartre, ningún determinismo: ni el teológico, acoplado a la voluntad de una divinidad; ni el marxista, coincidente con las leyes férreas de una historia que, en último término, haría converger la naturaleza física con una naturaleza humana esclava de su nomología inmutable.

Pero, mientras que Kant postulaba la idea de una razón no contaminada por las circunstancias históricas - un "deber ser" inmune a todo cambioel marxismo implicaría el esfuerzo por expresar racionalmente el torrente de irracionalidad que anida en la explotación del hombre por el hombre, expresión que solo puede llevarse a cabo mediante el cambio violento del statu quo. Se trata, en ambos casos, de un "liberarse de", pero con objetos de liberación contrarios entre sí. En la ética kantiana se aspira a estatuir sus principios prácticos, liberándose de la subjetividad, y en la ética marxista será la constatación de una subjetividad escindida en clases la que se convertirá en el motor de cambio de la realidad. Encumbradas a la categoría de mitos, ni la "razón pura" ni la "revolución pura" admitirán, respectivamente, concesiones subjetivas y revisionismos ideológicos.

Una característica de la racionalidad que no aparece lo suficientemente explícita en la ética kantiana es la capacidad de evaluar las consecuencias que han de tener las acciones. Esta capacidad, del mismo modo que otras facultades de la razón, no emergió súbitamente y no puede explicarse sino como efecto de una evolución neurofisiológica acompasada por las circunstancias, pero, en último término, coincidente en decir adiós a la animalidad. Dicho adiós, empero, nunca será definitivo. El ser humano está hecho de un barro en que la racionalidad misma puede trocarse en irracional (natura semper recurrit), no del todo moldeable, por ende, a los ideales de una llustración que, kantianamente interpretada, debería tender a la desaparición de la subjetividad. La impronta romántica y surrealista de la vida y obra de MVLI no dejan lugar a dudas: por ellas han pasado, dejando huella, las deficiencias y vacíos de una llustración no solo insatisfecha sino connaturalmente insatisfactoria. Ello, empero, no ha de implicar renunciar a la misión jerarquizadora de la razón en lo tocante a si, en el ámbito de la ética, "lo otro de la razón" misma (es decir, todo aquello que Kant subsumía en el concepto de "subjetividad") tendrá que estar supeditado a normas procedentes de instancias racionales. Jerarquizar no es disolver o hacer desaparecer el componente irracional, pero sí situarlo en un escalón inferior al de una razón crítica. Pese a la "validez restringida" que muestra el concepto de racionalidad, especialmente cuando es puesta en juego, con pretensiones demostrativas, por sistemas simbólicos (Ballón, 2001, pp. 45-47), la racionalidad no debe renunciar, en su dimensión práctica, a su tarea de discriminar lo bueno de lo malo,

3 La multiplicidad de las morales viene dada, no solo por las antropologías filosóficas en que se asientan, sino también por su diferente centro de fundamentación, esto es, Platón: el bien; los estoicos y Kant: la razón; Schopenhauer: la compasión; Darwin: la selección natural; Marx: la lucha de clases; Sartre: la moral; Apel y Habermas: la discusión racional (Comte-Sponville, 2012, p. 106). Todo ello pone de relieve que la razón no actúa sola, sino que está influenciada por vectores de fuerza subjetivos. 
esto es, a eximirse de la jerarquización moral a la que le conduce su esencia crítica (Kogan y Tubino, 2001, p. 61).

\section{El fundamentalismo de la razón}

¿Cabe la posibilidad de que la razón sea fundamentalista? Expresado con más concreción: ¿Puede la razón convencer al senderista de que su actuación es irracional? La llegada, vía la razón pura, a un "reino de los fines", lo mismo que, mediante la revolución comunista, a una sociedad igualitaria, es producto de un mecanismo de idealización en el que una determinada metodología se convierte en panacea dogmática de todos los males y en instancia descalificadora de lo otro de sí. Para el formalismo kantiano la ética de SL no sería racional, sino que obedecería al sojuzgamiento de la razón por parte de la subjetividad, mientras que el marxismo de SL, al otorgar superioridad a la razón dialéctica sobre la razón trascendental, juzgaría el contenido de la ética kantiana como un freno para la revolución y para la instauración de una verdadera democracia popular. De este modo, SL racionaliza un aspecto que Kant consideraría irracional.

El pensador de Königsberg, sin embargo, ostenta aquí una ventaja: en el caso del senderista, el formalismo de la razón pura no podría dictaminar su eliminación. No encuentra argumentos para declararlo "inhumano" y, por lo tanto, tampoco podría ser utilizado como "medio" para lo que decidiese la comunidad de los seres racionales. En SL, por el contrario, la desaparición de los que se oponen a sus principios éticos como metodología para arribar al comunismo constituye un imperativo que debe cumplirse necesariamente $y$, por lo mismo, puede también ser calificado de categórico.

Se ve interiormente (y se ve solo con la razón, esto es, ejerciendo de ser racional) lo que en el interior habita. ¿Qué es, sin embargo, lo que habita en el interior? No parece sostenible que su contenido sea a priori e ínsito innatamente en la conciencia moral y, por tanto, de validez y aplicación universales. Kant no veía lo mismo que lo que vio Abimael Guzmán, ni MVLI puede contemplar idéntica imagen a la de uno y otro: la diversidad de sus pertenencias culturales se lo impide. Ahora bien, si una misma realidad, según el marxismo, debería imprimir en la razón práctica idénticos imperativos morales debido a la relación inequívoca entre base-superestructura, ¿cómo explicar "visiones" tan disímiles? La teoría "fotográfica" del conocimiento es, a no dudarlo, una filosofía reduccionista de la complejidad de lo real, y puede conducir, por sus excesos simplificadores, a la confusión de toda la realidad con una parte de la misma y, como en la caverna platónica, a decretar la muerte del que piensa (o ve) un panorama diferente. No otra cosa es el fanatismo.

Kant se opondría a ayuntar los términos "fanatismo" y "razón", de ahí que resultaría impensable proponerle la redacción de una "crítica de la razón fanática". LA es, de manera indirecta pero elocuente, un esbozo meritorio en esa dirección y suministra materia prima como para diseñar una crítica de la razón irracional, cosa que Kant llevó a cabo tácitamente, pese a no admitir huellas de irracionalidad en la razón. En FMC se expone la crítica de la razón racional práctica, pero el problema que aquí surge es el siguiente: ¿a qué instancia le corresponde dictaminar la irracionalidad contenida en una razón que, al no ser pura, tampoco está libre de intereses? Teóricamente, la respuesta es sencilla: ha de ser la propia razón el tribunal máximo de apelación para erigirse en juez de la irracionalidad. Pero las teorías de la razón propias del formalismo kantiano y del marxismo senderista son tan contrarias entre sí que no podrán advenir a ningún acuerdo.

Ambos se creen representantes de la verdadera razón, mas en esa fe se produce, por así decirlo, una desrealización de la realidad humana, bien sea por un decreto a priori sobre cómo debería ser dicha realidad, bien sea empíricamente, es decir, extrayendo de la experiencia de una realidad injusta la necesidad de un cambio revolucionario. Para el marxismo no hay duda de que la ética kantiana implica una metarracionalidad que traiciona lo real; y para Kant la ética marxista quedaría incluida en una infrarracionalidad sustentada en las impurezas subjetivas. Expresado de otro modo: en ambas éticas se simplifica la complejidad del fenómeno humano y, por lo tanto, sus pretensiones de universalidad quedarán siempre truncas, no importando que, en un caso, la universalidad se estatuya en base a lo común y, en otro, se efectúe, apoyándose en la agudización de las diferencias. La razón, si se atiende a la complejidad de la realidad humana y a las pertenencias que la constituyen, es susceptible de ser también irracional. Pero en la irracionalidad no puede ser otra instancia, sino, más bien, la razón misma quien establezca su gradación respectiva. No es lo mismo matar al otro en nombre de una ideología, de una etnia, de una religión, o de una lengua (núcleo del que, según A. Maalouf (2005), se nutren las "identidades asesinas"), que proclamar que todo ser humano posee un valor supremo.

Ahora bien, si lo esencialmente humano (es decir, la "humanidad") existe como una idea a priori sin vinculación alguna con la experiencia, habría que suponer que esta última ha de definirse como la expresión de lo "inhumano", esto es, como "animalidad" monda y lironda. Pero lo esencialmente humano es —al igual que lo que sostenía Horkheimer acerca de la religión - un conglomerado de instintos proclives a la venganza $y$ al resentimiento que, insertados en la racionalidad, no mantienen relación alguna con el imperativo categórico (Cebrecos, 2013, p. 220). Fundamentándose en esta experiencia, y acoplándola a un dogmatismo teórico con pretensiones de validez universal, se construyen la ética y la política en el marxismo senderista; y puede afirmarse, por ello, que ambas son metamorfosis de dicho conglomerado. En el formalismo kantiano, empero, se procede al revés: se parte de una naturaleza humana ideal y se aspira a inocular en el ámbito a posteriori de la experiencia principios no tomados de esta. Tanto en el marxismo como en la ética kantiana no se renuncia - herencia ilustrada- a transformar las costumbres (ethos); dicha transformación, sin embargo, se ejerce mediante una metodología 
que le asigna a la razón procedimientos antagónicos.

No es lo mismo encontrar en la conciencia a Dios, como quería Descartes, 0 representarse en ella principios morales en los que el hombre se constituye en valor supremo, que toparse con el imperativo de asesinar al otro para que se produzca y se reproduzca la justicia. Sin embargo, de la paradójica reciprocidad con la que ambos procederes se calificarían entre sí de inmorales se desprende un interrogante ético inocultable: ¿quién ha de proponer las reglas de la moralidad? Si la racionalidad pura y la racionalidad derivada de la experiencia no pueden aportar principios prácticos de validez universal (minima moralia), parecería que la única respuesta posible habría de ser la de dejar su elaboración en manos de una racionalidad consensuada, la cual, por su parte, desembocará en otra cuestión no menos problemática: ¿y quiénes son hacedores y representantes legítimos del consenso?

La naturaleza humana kantiana es una naturaleza ideal que, en cuanto creación a priori, no da signos de existencia real. Esta última es la que justifica racionalmente el hecho de que en la conciencia haya de encontrarse lo que en ella pone la experiencia, tesis en la que se dan la mano, en contra de Kant, el realismo gnoseológico marxista y el empirismo vargasllosiano. Mas una ética totalmente dependiente de la subjetividad encerraría dentro de sí una contradicción insalvable para la vida social y haría imposible la convivencia. Ha de postularse, por ello, una base común de principios que sean universal y necesariamente obligantes, requisito incumplible si no se postula, a la vez, un fundamento último independiente de la experiencia y, por tanto, a priori. No importa la fuente de la cual proceda esta aprioridad y no importa tampoco, en esta coyuntura, saber que Kant la rechazaría si se la ubica en la conveniencia, en la fe religiosa o en una evolución humana que ha ido introyectando en la conciencia mandatos que, en un inicio, surgieron de imposiciones empíricas. Sin una "discusión racional" (Apel/Habermas) que garantice un cierto consenso en principios universalizables, la ética política quedará confinada exclusivamente al ámbito del deseo. Debe tenerse en cuenta, sin embargo, que la no excepción a la regla de tratar a los demás como fines en sí mismos solo podría darse, en principio, desde una "posición de igualdad" que asegure duración al compromiso contractual (Rawls, 1995, p. 173).

Es cierto que las éticas teleológicas subordinan los medios a un fin, pero ello no significa que todos los medios sean buenos, cupiéndole a la razón la tarea de discriminar su jerarquía. Dicha tarea, empero, no podrá efectuarse sin unir en la ética las dimensiones teleológica y deontológica, ya que los denominados principios mínimos morales han de alimentarse, en posición contraria a Kant, de los principios máximos que solo pueden ofrecer las éticas deontológicas. Ahora bien, como se verá más adelante, sin la hipótesis de que en todo ser humano se da una conciencia moral mínima y coincidente, por tanto, en ciertos principios prácticos (Blackburn, 2006, p. 28), la ética política de los minima moralia estaría condenada a un imposible surgimiento. La esperanza racional de que en la conciencia moral mínima, fuente primigenia de la ética política, pueda encontrarse universalmente que el imperativo "no matar" es éticamente superior al imperativo de "matar", no cierra, por sí sola, las puertas al retorno de SL o de otros movimientos violentistas. Es, sin embargo, un revulsivo kantiano en su contra y parece ser, también, el único fundamentalismo racionalmente justificable.

Todo ser racional posee la virtualidad de contemplar introspectivamente el interior de su conciencia moral. El hallazgo kantiano que suministra dicha introspección es el imperativo categórico, compendio de todas las otras leyes de la razón práctica. La mirada del senderista, dirigida por un método similar, no encuentra el imperativo kantiano, sino, antes bien, un imperativo hipotético al que él, premunido de la dialéctica marxista, lo reviste de las características de universalidad y necesidad. La hipótesis que subyace omnímodamente a su comportamiento revolucionario puede, por consiguiente, enunciarse así: "Si deseas que la revolución marxista -leninista-maoísta-pensamiento Gonza- lo triunfe en el Perú, tienes que eliminar al enemigo de clase y si, por desgracia, te encuentras en dicha condición, debes aceptar que tu muerte es justa". Ante tan dogmática constatación no hay escapatoria ética, ni posibilidad alguna de evadir la responsabilidad política que de ella se desprende.

Ahora bien, esta universalización dramática del fundamentalismo de la razón resulta incompatible con el "deber ser" de la ética kantiana. Kant reconoce que la razón práctica es un "hecho" (María von Herbert afirmará, en la carta anteriormente citada, que es un "hecho interno", una "vivencia racional"), pero no puede ser definida, a la manera del factum positivista, como algo cuya existencia no precise del pensamiento. Desde luego que su gnoseología le prohíbe declarar a Dios como autor de dicha razón, lo cual iría también, en último término, en contra de su "pureza de origen". Sin embargo, su carencia de raigambre teológica no impide afirmar que la "razón pura práctica" no estuviese libre de condicionamientos históricos 0 , lo que es lo mismo, no estuviese inmersa en una red de subjetividades que la hiciesen "impura". H.J. Paton (2005) puso hincapié en sus principales coordenadas: pietismo luterano, puritanismo materno y una primera educación religiosa imbuida de ambos componentes, además de la aversión al despotismo del viejo régimen, la herencia de Rousseau y del pensamiento ilustrado y, no por último menos importante, el entusiasmo inicial por una Revolución francesa reñida esencialmente con cualquier interpretación del "reino de los fines". Kant advino al factum de la razón pura "viniendo de otra cosa", que es el itinerario que Ortega y Gasset asignó a todo lo histórico, confirmándose así que la denominada "razón pura" nunca fue tal, sino, más bien, una razón histórica que registra en su génesis y en su desenvolvimiento las impurezas inherentes al mundo del hombre.

Es evidente que, desde la cúspide de una razón que se aísla intencionadamente de la subjetividad, se puede (y se debe) calificar de impuro a SL. Pero lo propio ha de suceder cuando, desde la entelequia de la utopía senderista, se juzga a la ética kantiana. Puro e impuro son adjetivaciones que, provenientes 
de la religión, tienen adyacencias dogmáticas y, por lo mismo, lindantes con un fanatismo que las amenaza. ¿Puede la razón, racionalmente administrada, conducir al fanatismo, 0 , más bien, la razón es, per se, un medio intolerante ante lo que ella, como tribunal dirimente de la praxis humana, determina como irracional? De hecho, se han cometido crímenes en nombre de la razón y, más concretamente, en nombre de una verdad así considerada por ella, de suerte que la razón no quedaría exenta de un comportamiento fanático. Kant, desde luego, recusaría esta conducta y la atribuiría, más bien, a una razón inficionada de elementos irracionales. De todos modos, aunque parezca paradójico, el antídoto más eficaz contra una razón histórica que carga sobre sus espaldas actos criminales (cuyo reato, por cierto, no es hereditario) (MVLI, El País, 3 de noviembre de 2013) ha de ser la razón misma, una razón que, en crítica despiadada de sus propios errores, haga posible una verdad consensuada acerca del fin que debe perseguir toda ética: una vida mejor para los seres humanos.

\section{Posibilidad e imposibilidad de diálogo}

En la aceptación de la hipótesis de un logos humano universal - tal como sucedía con los mens-ratio-animus de Descartes y con la Vernunft kantiana - tiene su origen la posibilidad del diálogo. En efecto, por ser común, el logos es también "comunicable", pero tal prerrogativa, de rancio abolengo griego, solo podrá cumplirse, kantianamente hablando, si la razón es "pura", 0, más concretamente, si posee "pureza de origen". Cuando la razón se mezcla con elementos extraídos empíricamente, y correspondientes, por tanto, a circunstancias supra- 0 infrarracionales, entonces la comunicación de lo común deviene en imposible y se convierte en un "diálogo de sordos". Por circunstancias suprarracionales se entiende aquí la fe religiosa y las convicciones políticas ideológicas arraigadas en un dogmatismo similar al de las religiones. De este bagaje, aun- que con diferente interpretación de lo que los marxistas denominan "superestructura", participan las iglesias y determinados partidos políticos. Las circunstancias infrarracionales están constituidas por ese mundo tan dispar (instintos, tendencias, apetencias, raza, historia, peruanidad) que Kant asignaba a la "subjetividad" y al "amado yo". En puridad de términos, tanto lo supra- como lo infrarracional se hallan anclados en el ámbito subjetivo y pueden, dependiendo del caso, intercambiar su jerarquía ontológica: Io infrarracional se eleva hacia el rango de lo suprarracional, y viceversa. De todos modos, kantianamente considerada, nunca debe estimularse la subjetividad en su faceta práctica por causas subjetivas; más bien, si estas intervienen, las acciones humanas quedan moralmente entorpecidas y contrahechas. Al contrario que la sangre y la luz, pertenecientes también a la subjetividad, la razón kantiana no admite compañías "purificadoras" ajenas a ella. Tampoco el marxismo será tolerante frente a quienes, doctrinaria 0 prácticamente, se opongan a una tesis considerada como "científica" e irrefutable: que la "purificación" social no podrá llevarse a cabo sin el derribo violento de las estructuras y personas en las que se asienta el statu quo.

¿Puede constituirse la violencia en vehículo comunicador de la racionalidad 0 , por el contrario, es la negación más elocuente de la posibilidad de diálogo? La respuesta de los episodios narrados en $L A$ suena concluyente: la ideología senderista, circunscrita a una realidad tan injusta y desigual como la de la sociedad peruana, convertirá la transformación social en una vorágine incontrolable de lo irracional, esto es, en una suerte de canibalismo, donde, en el altar de una ideología que promete un futuro feliz, son sacrificados los que dicha ideología señala previamente como víctimas. Salta a la vista que en dos intelecciones tan contrapuestas del logos, como son las éticas de Kant y de SL, todas las vías de diálogo estarán absolutamente cerradas.

\section{La oscilación dialéctica de la voluntad: autonomía y heteronomía}

Puede afirmarse que la idea más importante de la ética kantiana, puesta de relieve principalmente en la FMC, es la autonomía de la voluntad. En efecto, coincidente con el Sapere aude ("atrévete a saber") de la llustración, Kant perseguirá el ideal de una sociedad igualitaria y libre en la que el ser humano, como agente moral autónomo, postulará que no existe autoridad alguna —ni divina ni humana - que enseñe al hombre, en coacción heterónoma, el modo de comportarse. La autonomía de la voluntad ha de tener su fundamento en una razón práctica puramente racional, esto es, en una conciencia moral que no acepte imposición de ninguna ley proveniente de instancias ajenas a ella.

Los senderistas podían calificar a su voluntad de "buena", en cuanto se ajusta a las normas de su partido y coincide con sus bases ideológicas; consiguientemente, las voluntades disidentes serían "malas". Desde la ética kantiana, empero, esta percepción estaría equivocada, ya que la voluntad, al encontrarse presa en las redes de una subjetividad ideológica, no puede ser "libre". Sin embargo, permanecería incólume el imperativo de tratar al otro como a uno mismo, pues los miembros de SL, incluso si se afirma que no encuentran el mismo imperativo categórico que todos los demás seres racionales en su inspección del espíritu, no podrían ser tratados como "cosas" para los fines impuestos por otros seres racionales. El problema es, sin duda, más ímprobo de lo que a primera vista puede parecer, puesto que también cabe la posibilidad de creerse en posesión de la verdad ética y adjudicar el estatuto de "cosa" a quienes su naturaleza les sigue señalando como "fines en sí mismos". De todos modos, si el acento se carga en una voluntad autónoma, la ética kantiana demostraría también, a este respecto, su superioridad frente a la ética senderista. 
El "principio de laautonomía de lavoluntad", en tanto que "principio supremo de la moralidad" y en oposición a cualquier otro principio heterónomo, presupone una "voluntad legisladora universal” (FMC, pp. 120-122, pp. 131-132; Ak IV, núm. 431-433, 440). Dicha voluntad es conceptuada por Kant como una "especie de causalidad de los seres vivos, en cuanto son racionales", pero la propiedad de tal causalidad no es la "necesidad natural", sino la "libertad". Ahora bien, el ser humano, en cuanto no puede desentenderse de su corporalidad, participa de la "necesidad" propia de los "seres irracionales" y, por tanto, si la voluntad es movida por "un impulso ajeno insertado en la naturaleza del sujeto", entonces no se da a sí misma su propia ley y no puede ser calificada, en la práctica, de autolegisladora, sino de heterónoma (FMC, pp. 139, 137; Ak IV, núms. 446, 444). En este sentido, la voluntad autónoma es una "idea" (FMC, pp. 69-74; Ak IV, núm. 393-397) que se identifica con las de "voluntad buena" y "voluntad libre".

La casuística es la piedra de toque de la ética. En ella se dirime la viabilidad de la ley, se pone a prueba su necesidad $\mathrm{y}$, al igual que sucede en las ciencias referidas a hechos, ha de ser en la acción donde se contraste si deben introducirse cambios en los principios prácticos. Ahora bien, los casos concretos se dan en un hic et nunc que no estuvo necesariamente disponible en la elaboración de la teoría moral. La metodología ensayo-error se hará cargo, también aquí, de si la universalidad de la ley admite excepciones e introduce añadiduras. Esta es, sin duda, una ética material que MVLI no denegaría, aun cuando la experiencia, que nunca puede deshacerse del atributo de la individualidad, sea un criterio que se presta al relativismo moral y a una fundamentación aún más quijotesca (Maclntyre, 2007, p. 79) que el formalismo kantiano. El testimonio de que el lenguaje de la razón (légein) puede tener cabida en el lenguaje de la pasión (pathos), y viceversa, daría pábulo a una lectura antiilustrada de MVLI, aunque las secuelas del romanticismo y del surrealismo, siempre presentes en él, no parecen prevalecer sobre su fe en principios racionales que, especialmente en cuestiones de ética política, se muestran inconmovibles.

Desde una óptica kantiana, los senderistas no carecen de razón. Poseen, ciertamente, la capacidad introspectiva $\mathrm{y}$, desde luego, también una voluntad que, en principio, los hace libres para actuar o no actuar de acuerdo a determinadas normas. Lo que sucede es que, en ellos, la razón está inficionada de una subjetividad que impide que su voluntad sea "buena", ya que, al no encontrar dentro de sí el imperativo categórico común a todos los seres racionales, tampoco pueden querer obrar guiándose exclusivamente por él. Asignarles, entonces, el sambenito de la heteronomía resulta teóricamente comprensible, pero, en operación similar, también los senderistas podrían retrucar que los seres humanos jamás podrán ser libres mientras estén esclavizados por un orden social injusto e inhumano, cuya erradicación, tal como se demuestra en la historia, no puede ser obra de ninguna ética deontológica, sino de un consecuencialismo en que la lucha de clases se convierta en guía de la acción. De todos modos, el "querer", que es, tanto para Kant como para el marxismo —ambos herederos aquí de El contrato social (Rousseau, 1762)uno de los motores de la acción libre, no se identifica con el "poder". Y la historia demuestra también que una vez conseguido lo que la voluntad pretendió conseguir, la brecha entre ella y sus logros pondrá de relieve la dialéctica siempre abierta entre la autonomía (idea) de la voluntad y la heteronomía de un factum que la parcializa y deslegitima.

\section{El paso del "yo" al "nosotros": ética individual y ética política}

La ética, si bien encierra una dimensión individual y debe comenzar "por casa", no ha de ocultar el hecho de que el ser humano, como agente moral, tiene que realizar su vida en medio de la sociedad. Esta, tomada como realidad y no como idea utópica - pártase de un estado de naturaleza hobbesiano o roussoniano; privilégiese, respectivamente, la igualdad o la libertad-, es siempre de naturaleza conflictiva, de ahí que en Kant, al contrario, por ejemplo, que en Maquiavelo, Hobbes o Marx (pese, en este último, al paradigma irrealizable de una sociedad comunista), se encuentre, como consecuencia de su antirrealismo, un divorcio entre el "ser" y el "deber ser" que se revela en la asintoticidad del esfuerzo ("constreñimiento") por hacerlos coincidir. La eliminación de las circunstancias que rodean a un ser humano que, por naturaleza, es bueno, tendría que ser, en consideración política, la principal tarea de la ética. Pero Kant, que confiesa haber aprendido de Rousseau el "tomar conciencia de los derechos de la humanidad" y romper el individualismo, no propone ninguna metodología puntual para convertir su ideario en praxis política. El "reino de los fines" (Reich der Zwecke) es definido por él como el "enlace sistemático de distintos seres racionales por leyes comunes", lo cual supone prescindir de diferencias y de "fines privados" (FMC, p. 123; Ak IV, núm. 433). Se trata, por tanto, de una "idea" que entraña un concepto de comunidad ética y no, en primer término, de una comunidad política, aunque esta última, en cuanto tendencia "a la unanimidad de todos los "seres racionales finitos", constituiría un paso en dirección de la primera (Ak VI, p. 96).

Tanto la ética individual como la ética social han de guiarse en Kant por el prototipo del imperativo categórico, "ley de todas las leyes" y "paradigma hacia el que debemos esforzarnos por aproximarnos a su cumplimiento" (Urbild, welchem wir uns streben sollen zu nähern), tal como se lee en Metaphysik der Sitten (1798). La meta última que se desprende de la teoría no puede ser, sin embargo, la aproximación, sino el logro de igualarse a plenitud con lo que manda la razón práctica, fin que en la práctica posee una dimensión asintótica que hace posible que se hable de un "proceso indefinido" en lo que respecta a la consumación de la idea reguladora del "reino de los fines" (Ak V, pp. 83 y ss.; FMC, p. 123; Ak IV, núm. 433). 
El paso del "yo" al "nosotros" o, lo que es similar, el de una ética individual a una ética política, ha ocasionado, desde siempre, problemas en la interpretación de la ética kantiana y, debido a ello, Lucien Goldmann denominó "metafísica de la tragedia" a la filosofía práctica de Kant (1974, p. 166). Años antes, en Situaciones 2 ¿Qué es literatura? ([1948] 2003), Sartre había calificado de "abstracción lánguida" al reino kantiano de los fines, incidiendo en que era solo realizable "con una modificación objetiva de la situación histórica" (2003, p. 145). Sin embargo, uno de los mejores conocedores de la ética kantiana en nuestro idioma, el jesuita José Gómez Caffarena, no comparte dicha opinión. Según él, Kant ofrece en esta coyuntura una fundamentación esencial que no conviene perder de vista, ya que cada ser racional es un "fin en sí mismo" y, por ende, está dotado de una universalidad que le permite dar el "salto a lo colectivo". $Y$ añade: "...lo moral, en su contraste con el régimen de 'fines subjetivos', no se produce al margen del sistema de fines, sino por reconocer fines de igual dignidad en todos los demás sujetos racionales" (1978, p. 180).

A no dudarlo, es la universalidad de la razón —un presupuesto metafísico sin arraigo, como tal, en la realidad empírica - la que, aplicada a la ética social, ha de desembocar en el "reino de los fines". Kant sostiene que la moralidad consiste en una relación de toda acción con una legislación, también racional, donde la voluntad "pueda considerarse a sí misma como universalmente legisladora", esto es, se guíe por un principio que consiste en no efectuar ninguna acción que no esté vinculada a una "ley universal". Este requisito será necesario, como "intento filosófico", para tender "a la perfecta unificación ciudadana del género humano" y para "el establecimiento de una sociedad ciudadana que administre el derecho con mirada universal", tal como queda consignado en Idee zu einer allgemeinen Geschichte in weltbürglicher Absicht (Kant, 1968, VIII, p.17).

Resulta a todas luces patente la dimensión utópica de una política así planteada. Según Kant, los monarcas han de someterse de buen grado, 0 de fuerza ${ }^{4}$, a los designios de la razón, pero, paralelamente, ha de hacerlo también el pueblo. En efecto, la "ilustración del pueblo" —advierte en Metaphysik der Sitten — consistirá en "la instrucción pública respecto a los deseos y deberes del pueblo para con el Estado" (1968, VI, p. 489). En eso radica el "bien político soberano", pero su realización ha de enfrentarse, no solo a los conflictos creados por el uso colectivo de la autonomía de la libertad, sino a una disposición (Gesinnung) al mal que, como egoísmo, consiste en "anteponer a todo la máxima del propio interés", teniendo en cuenta que el ser humano es un "leño retorcido, del cual es casi imposible sacar nada derecho" (1968, VI, pp. 21, 25, 10; VIII, p. 23). Consiguientemente, el punto de llegada de dicha realización carece, en última instancia, de un topos localizable, pero su "bien sumo" - tal como se lee en Die Religion innerhalb der Grenzen der blossen Vernunft- consiste en fundar un "reino de Dios sobre la tierra", es decir, una suerte de estado civil ético en el cual los hombres estarían unidos bajo "leyes de virtud no coactivas".

Una sociedad como la kantiana, igualitaria, proyectada hacia un reino de los fines en el que los seres racionales estén vinculados necesaria y universalmente por leyes comunes, implicaría, por el carácter legislador de todo ser racional, la llegada a un anarquismo ideal en que 0 bien no existiría la legalidad, o bien esta se identificaría de lleno con la moralidad. Se trataría, pues, de un monon ético sin conexión con las sensaciones, apetitos y tendencias subjetivos $y$, paradójicamente, sin poder lograr una felicidad total, ya que esta, concebida también como idea, no es otra cosa que la satisfacción de todas las inclinaciones a la vez (FMC, p. 77; Ak IV, núm. 399). El advenimiento de una Respublica noumenon solo podría ser posible si, previamente, se hubiesen cerrado las puertas a una Respublica fenoménica, esto es, si se hubiese eliminado de raíz el realismo político. Pero la "cosa pública" no admite, sino negándose a sí misma, que sea un solo principio rector (monarquía, "reino de los fines") el que gobierne a unos ciudadanos cuya naturaleza tiende, más bien, hacia el pluralismo ideológico y la diversidad política. Desde la utopía irrealizable, el reino de los fines garantizaría, eso sí, un "amor práctico" irreductible a categorías eudemonistas y fundamentado tan solo en una voluntad buena, porque si tuviese su sede en las tendencias propias de la sensación, sería —así lo califica Kant- un "amor patológico" (FMC, p. 78; Ak IV, núm. 399), único amor que podría derivarse del realismo político.

Visto a la luz del marxismo (y también, desde luego, del utilitarismo y de las éticas consecuencialistas), el amor kantiano, precisamente por no estar enraizado en un pathos que también es parte constitutiva de la naturaleza humana, resulta siendo una entelequia ideal, algo así como una suerte de amor intellectualis Dei (Spinoza), o de gratificación metafísica post mortem en un mundo imaginario en el que la lucha de clases no tuviese razón de ser. Así, pues, como sucede en tantos aspectos de la ética kantiana, puede distinguirse aquí - tal como advierte Félix Duque - un ars exponendi dual, propio de una lógica binaria: el hombre es un medio insustituible para estatuir el reino de los fines, pero, a la vez, este será posible solamente si, en contraposición, se concibe al ser humano, en tanto que persona, como representante de la humanidad, es decir, como un fin en sí mismo (2009, pp. 61-71). Ahora bien, en el concepto kantiano de persona no es la comunidad la que prevalece sobre el individuo, esto es, no se trata aquí de una communio. José Luis Villacañas prefiere, por eso, hablar de una interacción recíproca entre individuos (commercium), que sería la posición política por la que Kant se decanta. "Sin embargo - escribe el mismo autor-, de ello no puede deducirse que la posición kantiana sea asimilable sin más a la de los defensores del liberalismo, enfrentados a las posturas comunitaristas" (2009, pp. 89-104).

De todos modos, no habría reino de los fines sin vinculación a la autonomía del imperativo categórico, aun cuando, por su imperfección ontológica, se necesite que la voluntad sea "constreñida", ya que, "como sucede realmente en los hombres" (FMC, p. 96; Ak IV, núm. 413), no coincide exhaustivamente con el contenido de los principios morales de la razón práctica. El esfuerzo desplegado por 
el ser humano para hacer coincidir, en lo posible, voluntad humana y razón práctica - implica que la raíz de la moralidad no sea otra que la libertad.

El advenimiento al "reino de los fines", al igual que los cielos y la tierra nuevos del cristianismo, no puede darse sin la renuncia a las exigencias de "lo otro de la razón" (llámese subjetividad, "carne", o una corporeidad situada en un Sitz im Leben asido irremediablemente a la materia física). Tampoco la llegada a la sociedad comunista como etapa final del materialismo histórico dialéctico estará exenta de elementos purificadores, los cuales implicarán, de hecho, una ética del constreñimiento. Sin embargo, ni en Kant ni en el cristianismo podrá hablarse de una metodología que, para llegar a su télos final, presuponga la muerte intencionada de ningún ser humano. Ya se sabe cuál será aquí la posición de MVLI.

En efecto, lo que sucede cuando lo racional es engullido por lo subjetivo no puede liberarse de lo que él ha denominado, en un término sin duda provocativo, "fascismo". "Fascismo afirma - significa un régimen vertical y caudillista, que elimina toda forma de oposición y, mediante la violencia, anula 0 extermina las voces disiden- tes; un régimen invasor de todos los dominios de la vida de los ciudadanos, desde el económico hasta el cultural y, principalmente, claro está, el político; unanimidad del miedo y el silencio y una frenética demagogia". En este "trasfondo ideológico — añade, apelando a Jean-François Revel- se funden y confunden" todos los totalitarismos: "fascismo, leninismo, estalinismo, castrismo, maoísmo, chavismo" ("La libertad en las calles", en El País, 9 de marzo de 2014). Pocas dudas han de caber aquí acerca del lugar que para MVLI ocuparía SL.

\section{Bibliografía}

Aleu Benítez, J. (1987). Filosofía y libertad en Kant. Barcelona: Promociones Publicaciones Universitarias.

Balón, J. C. (2001). El fin del horizonte cartesiano en las Ciencias Sociales. En M. Heise (comp. y ed.), Interculturalidad. Creación de un concepto y desarrollo de una actitud. Lima: Programa Forte-Pe.

Bцосн, E. (1985a). Das Prinzip Hoffnung. Fráncfort del Meno: Suhrkamp.

Bıоch, E. (1985b). Geist der Utopie. Fráncfort del Meno: Suhrkamp.

BlackbuRn, P. (2006). La ética. Fundamentos y problemáticas contemporáneas. México, D. F.: Fondo de Cultura Económica.

Cebrecos, F. (2013). Sobre Dios, el hombre y la muerte. Tres aproximaciones filosóficas. Lima: Fondo Editorial de la Universidad de Lima.

Comte-Sponville, A. (2012). La filosofía. Qué es y cómo se practica. Barcelona: Paidós.

Duaue, F. (2009). El reino de los fines es el reino de los medios. Logos. Anales del Seminario de Metafísica, (42), 61-71.

Gómez Caffarena, J. (1978). Respeto y utopía, ¿dos fuentes de la moral kantiana? Pensamiento, (34), 259-276.

Goldmann, L. (1974). Introducción a la filosofía de Kant. Buenos Aires: Amorrortu.

HiRschBeRger, J. (1965). Historia de la filosofía. Barcelona: Herder.

Kant, I. (1968). Kants Werke. Berlín: Walter de Gruyter \& Co.

Kant, I. (2005). Fundamentación de la metafísica de las costumbres. Madrid: Tecnos.

Kogan, L., y Tubino, F. (2001). Identidades culturales y políticas de reconocimiento. En M. Heise (comp. y ed.), Interculturalidad. Creación de un concepto y desarrollo de una actitud. Lima: Programa Forte-Pe.

Lafuente, F. R. (1993). Prólogo. En Vargas Llosa, M. Lituma en los Andes. Barcelona: Planeta.

Maalouf, A. (2005). Identidades asesinas. Madrid: Alianza Editorial.

MaclntrRe, A. (2007). After Virtue. Notre Dame, Indiana: University of Notre Dame. 
Montero, R. (10 de febrero de 2015). Continuidad. Y además: ¿quién va a defender a esos pobres, mudos animales, si no lo hacemos nosotros? El País. Recuperado de http://elpais.com/elpais/2015/02/09/opinion/1423493015_255686.html

Montaigne, M. DE. (2009 [1595]). Essais. París: Editions Pocket.

Morin, E. (1973). Le paradigme perdu. L'a nature humaine. París: Seuil.

Nozık, R. (1995). La naturaleza de la racionalidad. Barcelona: Paidós.

PauL, R. (1990). Critical Thinking: What Every Person Needs to Survive in a Rapidy Changing World. Sonoma, CA: Sonoma State University.

Paton, H. J. (1970). The Categorical Imperative. A Study in Kant's Moral Philosophy. Londres: Hutchinson.

Paton, H. J. (2005). The Moral Law: Groundwork of the Metaphysic of Morals. Immanuel Kant. Londres: Routledge.

Rawls, J. (1995). Teoría de la justicia. México, D. F.: Fondo de Cultura Económica.

Rodríguez Aramayo, R. (1987). La filosofía de la historia en Kant. Una encrucijada de su pensamiento moral y político. En C. La Rocca, J. M. Ripalda, F. Duque, et al., Eticidad y Estado en el idealismo alemán. Valencia: Natán.

Rovira, R. (2012). Las principales disciplinas filosóficas cultivadas en la actualidad. En J. J. García Narro (coord.), Convirtiéndose en filósofo. Estudiar filosofía en el siglo xxı. Madrid: Síntesis.

SARTRE, J.-P. (1999). El existencialismo es un humanismo. Barcelona: Edhasa.

SARTRE, J.-P. (2003). ¿Qué es la literatura? Buenos Aires: Losada.

Villacañas, J. L. (2009). Lo común en Kant. Logos. Anales del Seminario de Metafísica, (42), 89-104.

Vargas Llosa, M. (1993). Lituma en los Andes. Barcelona: Planeta.

Vargas Llosa, M. (27 de agosto de 1995). La señal de la cruz. El País. Recuperado de http://elpais.com/ diario/1995/08/27/opinion/809474409_850215.html

Vargas Llosa, M. (11 de octubre de 1998). El nasciturus. El País. Recuperado de http://elpais.com/ diario/1998/10/11/opinion/908056807_850215.html

Vargas Llosa, M. (22 de noviembre de 1998). El sexo débil. El País. Recuperado de http://elpais.com/ diario/1998/11/22/opinion/911689206_850215.html

Vargas Llosa, M. (25 de julio de 1999). Los pies de Fataumata. El País. Recuperado de http://elpais.com/ diario/1999/07/25/opinion/932853606_850215.html

Vargas Llosa, M. (18 de abril del 2010). Torear y otras maldades. El País. Recuperado de http://elpais.com/ diario/2010/04/18/opinion/1271541611_850215.html

Vargas Llosa, M. (12 de agosto del 2012). La "barbarie" taurina. El País. Recuperado de http://elpais.com/ elpais/2012/08/08/opinion/1344422417_734411.html

Vargas Llosa, M. (3 de noviembre del 2013). Los parias del Caribe. El País. Recuperado de http://elpais.com/ elpais/2013/10/31/opinion/1383233998_965346.html

Vargas Llosa, M. (2014), “La libertad en las calles", en diario El País, 9 de marzo. Recuperado de http://elpais.com/ elpais/2014/03/06/opinion/1394116119_987776.html 